\title{
Caffeic Acid Inhibits RANKL and TNF- $\alpha$-induced Phosphorylation of p38 Mitogen-activated Protein Kinase in RAW-D Cells
}

\author{
Ferry Sandra ${ }^{1,2, *}$, Ketherin ${ }^{3}$ \\ ${ }^{1}$ Department of Biochemistry and Molecular Biology, Division of Oral Biology, Faculty of Dentistry, Universitas Trisakti, J1. Kyai Tapa No.260, \\ Jakarta, Indonesia \\ ${ }^{2}$ BioCORE Laboratory, Faculty of Dentistry, Universitas Trisakti, Jl. Kyai Tapa No.260, Jakarta, Indonesia \\ ${ }^{3}$ Faculty of Dentistry, Universitas Trisakti, Jl. Kyai Tapa No.260, Jakarta, Indonesia \\ *Corresponding author. E-mail: ferrysandra@gmail.com
}

Received date: Feb 7, 2018; Revised date: Mar 14, 2018; Accepted date: Mar 15, 2018

\section{Abstract}

B ACKGROUND: Caffeic acid inhibits osteoclastogenesis by downregulating expression of Cathepsin K and Nuclear Factor of Activated T cells (NFATc)1, as well as inhibiting activity of Nuclear Factor $\kappa \mathrm{B}(\mathrm{NF \kappa B})$. Meanwhile TNF Receptor-associated Factor (TRAF)6 was not influenced by caffeic acid. In order to investigate further caffeic acid's mechanism in inhibiting osteoclastogenesis, regulation of caffeic acid on p38 Mitogen-activated Protein Kinase (MAPK) was investigated.

METHODS: RAW-D cells were pretreated with/without caffeic acid and treated with/without $20 \mathrm{ng} / \mathrm{mL}$ RANKL and $1 \mathrm{ng} / \mathrm{mL}$ TNF $\alpha$ for $0.2,1,6$, and 12 hour. Tartrate Resistant Acid Phosphatase (TRAP) staining was performed. Then, western blot analysis was performed to detect p38 MAPK and phosphorylated-p38 MAPK. Resulted protein bands were quantified and statistically analyzed.
RESULTS: Under induction of $20 \mathrm{ng} / \mathrm{mL}$ RANKL and $1 \mathrm{ng} /$ mL TNF- $\alpha$, RAW-D cells were successfully differentiated into $\mathrm{TRAP}^{+}$osteoclast-like polynuclear cells. Under treatment of $20 \mathrm{ng} / \mathrm{mL}$ of RANKL and $1 \mathrm{ng} / \mathrm{mL}$ of TNF- $\alpha$ for 0.2 or 1 hour, significant ( $p=0,000$, T test) increment of phosphorylated p38 MAPK was observed as compared with control. Pretreatment of $10 \mu \mathrm{g} / \mathrm{mL}$ caffeic acid significantly ( $p=0.000$, T test) suppressed the $20 \mathrm{ng} / \mathrm{mL}$ of RANKL and $1 \mathrm{ng} / \mathrm{mL}$ of TNF- $\alpha$-induced phosphorylation of $\mathrm{p} 38$ MAPK.

CONCLUSION: RANKL and TNF- $\alpha$ are potent osteoclastogenesis inductors in RAW-D cells, meanwhile caffeic acid could inhibit the RANKL and TNF $\alpha$-induced osteoclastogenesis through p38 MAPK.

KEYWORDS: caffeic acid, osteoclastogenesis, RANKL, TNF- $\alpha$, p38, MAPK, RAW-D cells

Indones Biomed J. 2018; 10(2): 140-3

\section{Introduction}

Osteoclastogenesis, the development of osteoclast from precursor polynuclear cells (PNCs), could be induced by several factors, including Tumor Necrosis Factor (TNF) and Receptor Activator of Nuclear Factor $\kappa \mathrm{B}$ (RANK) Ligand (RANKL).(1,2) The osteoclastogenesis related factors could be produced in the physiological development process $(3)$, inflammatory process $(3,4)$ and intraosseous tumor development process (5). After the binding of osteoclastogenesis ligands to their receptors, osteoclastogenesis signaling pathways were activated. The bindings of RANKL to RANK and TNF to TNF receptor (TNFR) can further lead to the activation of the Mitogenactivated Protein Kinase (MAPK) family.(6,7) Among the MAPK family, p38 MAPK has been reported to play an important role in osteoclastogenesis. $(8,9)$

Caffeic acid attracts much special attention because of its ability to protect the human from several diseases, 
including cancer $(10,11)$ and bone resorption (12-14). Caffeic acid induced osteosarcoma cells into apoptosis by activation of Caspases, including Caspase- $8,-9$ and -3. $(10,11)$ Meanwhile in order to protect from bone resorption, caffeic acid targets osteoclastogenesis.(12-14) Caffeic acid did not induce apoptosis in PNCs (12), but it inhibited osteoclastogenesis by inhibiting expression of Cathepsin K and Nuclear Factor of Activated T cells (NFATc)1 (13), as well as inhibiting activity of Nuclear Factor $\kappa \mathrm{B}(\mathrm{NF \kappa B})(12)$. However, caffeic acid did not target the expression of TNF Receptor-associated Factor (TRAF)6.(14) In order to investigate further caffeic acid's mechanism in inhibiting osteoclastogenesis, regulation of caffeic acid on p38 MAPK was investigated.

\section{Methods}

\section{Cell Culture}

RAW-D cells were cultured in $\alpha$-MEM (GIBCO-BRL, Grand Island, NY) with 10\% FBS (Biosource, Camarillo, $\mathrm{CA})$ at $37^{\circ} \mathrm{C}$ in a humidified incubator with $5 \% \mathrm{CO}_{2}$.

\section{in vitro Osteoclastogenesis}

Six thousand RAW-D cells were cultured in each well of a 96-well plate with the complete culture medium. Pretreatment of $10 \mu \mathrm{g} / \mathrm{mL}$ caffeic acid (Wako, Osaka, Japan) was conducted for 2 hours prior to the treatment of $20 \mathrm{ng} /$ mL RANKL (PeproTech, London, UK) and 1 ng/mL TNF- $\alpha$ (Roche Molecular Biochemicals, Mannheim, Germany). Three days later, Tartrate Resistant Acid Phosphatase (TRAP) staining using Leukocyte Acid Phosphatase Kit (Sigma-Aldrich, St. Louis, MO) was performed. TRAP ${ }^{+}$ PNCs were documented under an inverted microscope.

\section{Western Blot}

Treated cells were harvested and incubated with lysis buffer containing $10 \mathrm{mM}$ Tris buffer (pH 7.4), $150 \mathrm{mM} \mathrm{NaCl}, 1 \%$
Triton-X100 and $100 \mu \mathrm{L}$ protease inhibitor cocktail (SigmaAldrich, St.Louis, MO). The proteins in the samples were separated by sodium dodecyl sulfate (SDS)-polyacrylamide gel electrophoresis and transferred to a nitrocellulose membrane (Biorad, Richmond, CA). After blocking with $5 \%$ skim milk in phosphate buffer saline (PBS) ( $\mathrm{pH} 7.4$ ), the membrane were probed with 1:1000 diluted rabbit polyclonal anti-phospho-p38 MAPK (Thr180/Tyr182) antibody (Cell Signaling Technology, Danvers, MA). The secondary antibody was 1:2000 diluted horseradish peroxidase-conjugated donkey anti-rabbit antibody (Cell Signaling Technology). The bound antibodies were visualized using Immun Star HRP Chemiluminescent Kit (Bio-Rad Laboratories, Hercules, CA). Membrane was then stripped with Seppro stripping buffer (Sigma-Aldrich), blocked with $5 \%$ skim milk in PBS, probed with rabbit polyclonal anti-p38 MAPK (Cell Signaling Technology), bound with same secondary antibody and visualized with the chemiluminescent kit. All visualized bands were captured using Alliance 4.7 (UVItech, Cambridge, UK) and quantified using UVIband software (UVItech).

\section{Statistical Analysis}

Analyses were performed using IBM SPSS for Windows version 20.0 (IBM Corp., Armonk, NY). T-test was used to determine the statistical differences between the means of experiments. A probability value $<0.05$ was considered to be statistically significant.

\section{Results}

Caffeic acid inhibited RANKL and TNF $\alpha$-induced osteoclastogenesis in RAW-D Cells

Under induction of $20 \mathrm{ng} / \mathrm{mL}$ RANKL and $1 \mathrm{ng} / \mathrm{mL}$ TNF $\alpha$, RAW-D cells were successfully differentiated into TRAP ${ }^{+}$ osteoclast-like PNCs (Figure 1B). However, by adding 10 $\mu \mathrm{g} / \mathrm{mL}$ caffeic acid prior to induction of $20 \mathrm{ng} / \mathrm{mL}$ RANKL
A

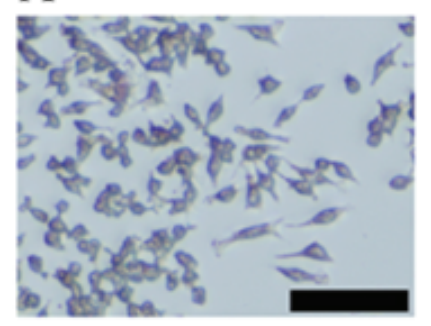

B

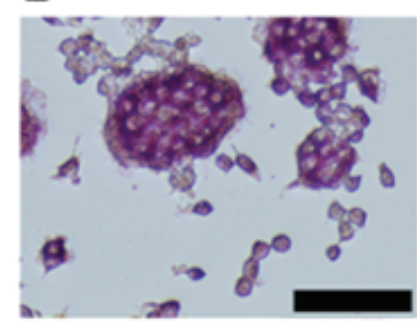

C

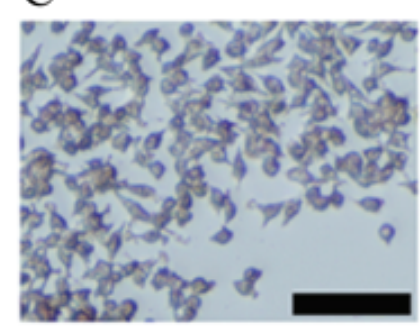

Figure 1. Caffeic acid inhibited RANKL and TNF- $\alpha$-induced osteoclastogenesis in RAW-D cells. A: Untreated RAW-D cells. B: RAW-D cells were treated with $20 \mathrm{ng} / \mathrm{mL}$ of RANKL and $1 \mathrm{ng} / \mathrm{mL}$ of TNF- $\alpha$. C: RAW-D cells were pretreated with $10 \mu \mathrm{g} / \mathrm{mL}$ caffeic acid and treated with $20 \mathrm{ng} / \mathrm{mL}$ of RANKL and $1 \mathrm{ng} / \mathrm{mL}$ of TNF- $\alpha$. Bar: $100 \mu \mathrm{m}$. 
and $1 \mathrm{ng} / \mathrm{mL} \mathrm{TNF} \alpha, \mathrm{TRAP}^{+}$osteoclast-like PNC was not found (Figure 1C).

\section{Caffeic Acid inhibited RANKL and TNF $\alpha$-induced Phosphorylation of p38 MAPK in RAW-D Cells}

Under treatment of $20 \mathrm{ng} / \mathrm{mL}$ of RANKL and $1 \mathrm{ng} / \mathrm{mL}$ of TNF- $\alpha$ for 0.2 or 1 hour, significant ( $p=0,000$, T test) increment of phosphorylated p38 MAPK was observed as compared with control (Figure 2). Treatment of $20 \mathrm{ng} / \mathrm{mL}$ of RANKL and $1 \mathrm{ng} / \mathrm{mL}$ of TNF- $\alpha$ for 6 and 12 hours did not induce phosphorylation of p38 MAPK. Pretreatment of $10 \mu \mathrm{g} / \mathrm{mL}$ caffeic acid significantly ( $p=0,000$, T test) suppressed the $20 \mathrm{ng} / \mathrm{mL}$ of RANKL and $1 \mathrm{ng} / \mathrm{mL}$ of TNF$\alpha$-induced phosphorylation of p38 MAPK.

\section{Discussion}

Previous study has shown that caffeic acid did not significantly affect the expression of TRAF6 while significantly inhibited NFKB's activity in RANKL and TNF$\alpha$-induced TRAF6 transfected-RAW-D cells.(14) Despite TRAF6, the involvement of MAPK in the osteoclastogenesis signaling process induced by RANK-RANKL has been widely recognized.(6-9) MAPK is an enzyme that converts extracellular stimulus into various cellular responses. p38 MAPK is a member of MAPK family that has an important role in tissue development and homeostasis functions such as cell differentiation, apoptosis, maturation, and cytokine production which initiates osteoclastogenesis. $(8,9)$ After being activated, p38 MAPK will induce important transcription factors such as NFkB and NFATc1. $(8,9,12)$ Inhibition of p38 MAPK was reported to fully diminish
RANKL and TNF- $\alpha$-induced osteoclast formation.(15) In the present study, RANKL and TNF- $\alpha$ induced formation of TRAP $^{+}$PNCs, meanwhile pretreatment of caffeic acid could diminish the formation of RANKL and TNF- $\alpha$ induced TRAP ${ }^{+}$PNCs. The upregulated phosphorylation of p38 MAPK was clearly observed in RANKL and TNF- $\alpha-$ induced RAW-D cell, meanwhile pretreatment of caffeic acid could diminish the phosphorylation of p38 MAPK.

RANKL and TNF- $\alpha$ which induce bone loss, can be secreted by activated $\mathrm{T}$ and $\mathrm{B}$ cells in inflammatory states.(16) Inhibition on RANKL and TNF- $\alpha$-induced osteoclastogenesis by some agents has been reported, including osteoprotegerin (17), Simon extract (13) and its constituent, caffeic acid (10,12-14). However, mechanism of caffeic acid in inhibiting osteoclastogenesis remained unclear. Current study has shown that 38 MAPK is one of the second messengers that plays an important role in RANKL and TNF- $\alpha$-induced osteoclastogenesis. A schematic signaling pathway of RANKL-induced osteoclastogenesis in RAW-D cells can be seen in Figure 3. based on current results and previous report, caffeic acid is shown to inhibit activation of NFKB and p38 MAPK. Further investigation for other activated second messengers should be pursued.

\section{Conclusion}

Taken together, current results suggested that RANKL and TNF- $\alpha$ are potent osteoclastogenesis inductors in RAW-D cells, meanwhile caffeic acid could inhibit the RANKL and TNF- $\alpha$-induced osteoclastogenesis through p38 MAPK.

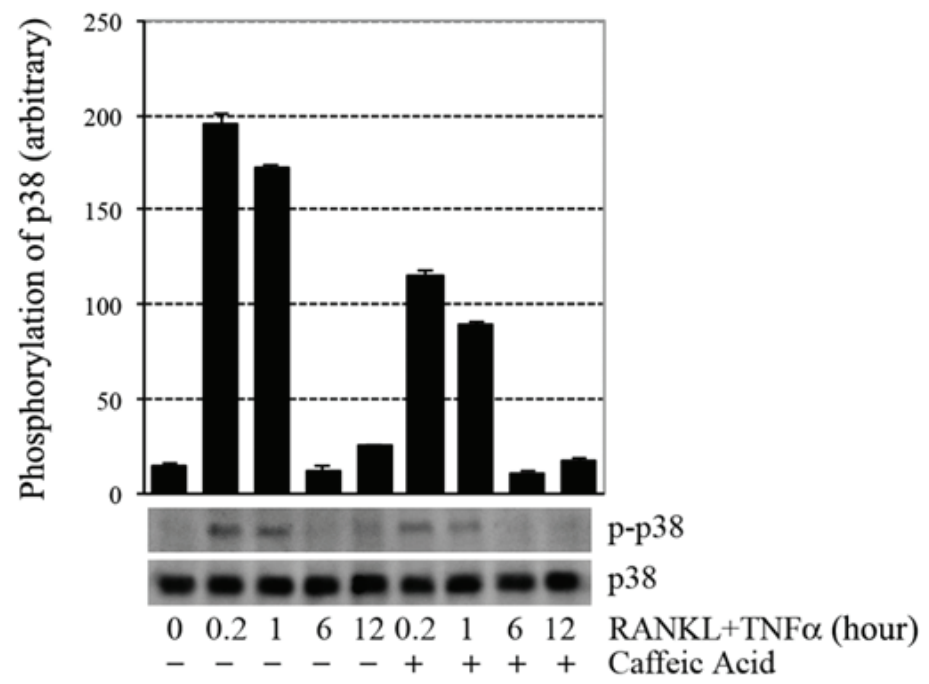

Figure 2. Caffeic acid inhibited RANKL and TNF$\alpha$-induced phosphorylation of p38 in RAW-D cells. RAW-D cells were pretreated with/without 10 $\mu \mathrm{g} / \mathrm{mL}$ caffeic acid and treated with/without $20 \mathrm{ng} /$ $\mathrm{mL}$ of RANKL and $1 \mathrm{ng} / \mathrm{ml}$ of TNF- $\alpha$ for $0,0.2$, 1,6 and 12 hours. Cells were lysed and subjected to immunoblotting assay using anti-p38 and antiphosphorylated p38 antibodies. Data represent a typical result from 3 independent experiments. 


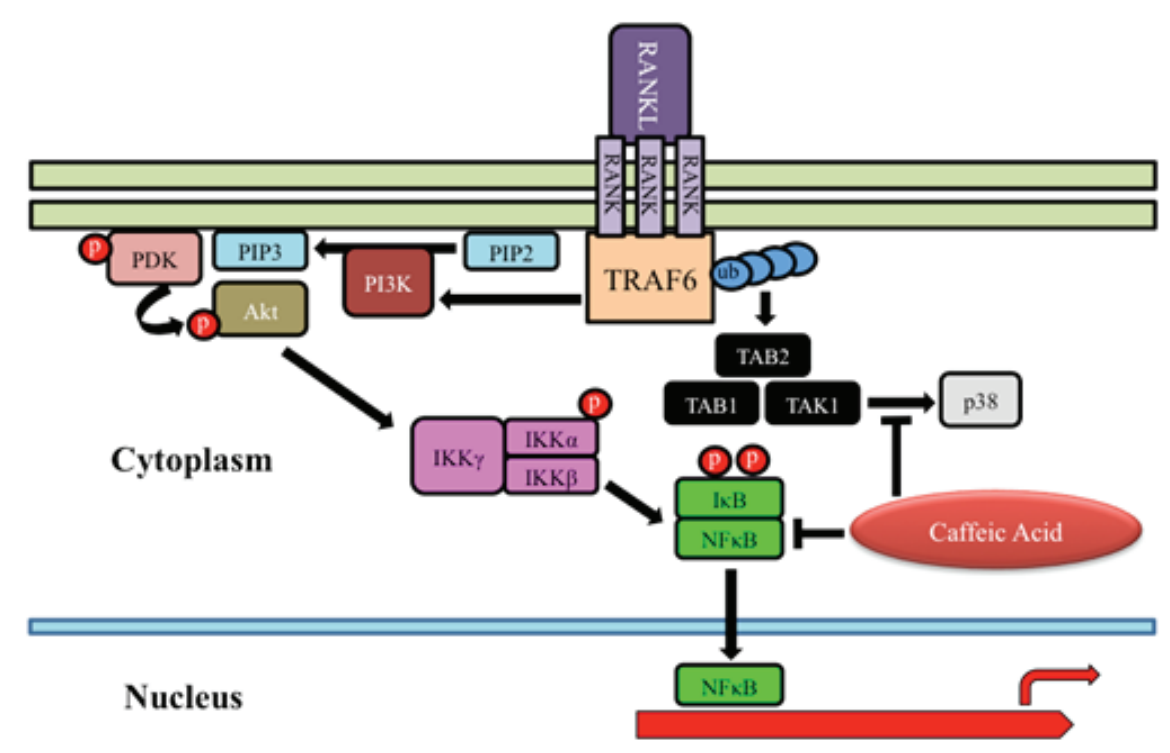

Figure 3. Signaling pathway of RANKL-induced osteoclastogenesis in RAW-D cells.

\section{References}

1. Kukita T, Wada N, Kukita A, Kakimoto T, Sandra F, Toh K, et al. RANKL-induced DC-STAMP is a key transmembrane molecule in osteoclastogenesis. J Exp Med. 2004; 200: 941-6.

2. Toh K, Kukita T, Wu Z, Kukita A, Sandra F, Tang QY, et al. A possible involvement of MIP-1 $\alpha$ in the recruitment of osteoclast progenitors to the distal tibia in rats with adjuvant-induced arthritis. Lab Invest. 2004; 84: 1092-102.

3. Horowitz MC, Xi Y, Wilson K, Kacena MA. Control of osteoclastogenesis and bone resorption by members of the TNF family of receptors and ligands. Cytokine Growth Factor Rev. 2001; 12: 9-18.

4. Xing L, Schwarz EM, Boyce BF. Osteoclast precursors, RANKL/ RANK, and immunology. Immunol Rev. 2005; 208: 19-29.

5. Sandra F, Hendarmin L, Kukita T, Nakao Y, Nakamura N, Nakamura S. Ameloblastoma induces osteoclastogenesis: A possible role of ameloblastoma to proliferate in the bone. Oral Oncol. 2005; 41: 637-44.

6. Clark J, Vagenas P, Panesar M, Cope AP. What does tumour necrosis factor excess do to the immune system long term? Ann Rheum Dis. 2005; 64 (Suppl 4): 70-6.

7. Lee K, Chung YH, Ahn H, Kim H, Rho J, Jeong D. Selective regulation of MAPK signaling mediates RANKL-dependent osteoclast differentiation. Int J Biol Sci. 2016; 12: 235-45.

8. Cong Q, Jia H, Li P, Qiu S, Yeh J, Wang Y, et al. p38 $\alpha$ MAPK regulates proliferation and differentiation of osteoclast progenitors and bone remodeling in an aging-dependent manner. Sci Rep. 2017; 7: 45964. doi: 10.1038/srep45964.
9. Kang JH, Lim H, Jeong JE, Yim M. Attenuation of RANKL-induced osteoclast formation via p38-mediated NFATc1 signaling pathways by extract of euphorbia lathyris L. J Bone Metab. 2016; 23: 207-14.

10. Sandra F, Sidharta MA. Caffeic acid induced apoptosis in MG63 osteosarcoma cells through activation of caspases. Mol Cell Biomed Sci. 2017; 1: 28-33.

11. Sandra F, Hudono KF, Putri AA, Putri CAP. Caspase inhibitor diminishes caffeic acid-induced apoptosis in osteosarcoma. Indones Biomed J. 2017; 9: 160-4.

12. Sandra F, Kukita T, Tang QY, Iijima T. Caffeic acid inhibits NFkB activation of osteoclastogenesis signaling pathway. Indones Biomed J. 2011; 3: 216-22.

13. Tang QY, Kukita T, Ushijima Y, Kukita A, Nagata K, Sandra F, et al. Regulation of osteoclastogenesis by Simon extracts composed of caffeic acid and related compounds: successful suppression of bone destruction accompanied with adjuvant-induced arthritis in rats. Histochem Cell Biol. 2006; 125: 215-25.

14. Sandra F, Kukita T, Muta T, Iijima T. Caffeic acid inhibited receptor activator of nuclear factor $\mathrm{\kappa B}$ ligand (RANKL)-tumor necrosis factor (TNF) $\alpha$-TNF receptor associated factor (TRAF) 6 induced osteoclastogenesis pathway. Indones Biomed J. 2013; 3 : 173-8.

15. Thouverey C, Caverzasio J. Focus on the p38 MAPK signaling pathway in bone development and maintenance. Bonekey Rep. 2015; 4: 711.

16. Weitzmann MN. Bone and the immune system. Toxicol Pathol. 2017; 45: 911-24.

17. Sandra F, Hendarmin L, Nakamura S. Osteoprotegerin (OPG) binds with tumor necrosis factor-related apoptosis-inducing ligand (TRAIL): suppression of TRAIL-induced apoptosis in ameloblastomas. Oral Oncol. 2006; 42: 415-20. 